\title{
Usefullness of P-wave and QT Dispersions for Predicting Early Death in Patients with Acute Pulmonary Embolism
}

\section{Akut Pulmoner Embolili Hastalarda Erken Olumu Ongormede P Dalgası ve QT Dispersiyonlarinin Faydasi}

\author{
Çağdaş Akgüllü', Ufuk Eryllmaz', Evrin Dağtekin', Mehmet Akdeniz', Hasan Güngör', Cemil Zencir', İmran Kurt Ömürlü² \\ 'Department of Cardiology, Adnan Menderes University Faculty of Medicine, Aydın, Turkey \\ 2Department of Biostatistics, Adnan Menderes University Faculty of Medicine, Aydın, Turkey
}

\section{Abstract}

OBJECTIVE: We aimed to demonstrate and compare to each other the relations of QT and $\mathrm{P}$ wave dispersions with early death in the course of acute pulmonary embolism (PE).

MATERIALS AND METHODS: The archive data of 124 patients who had been hospitalized in our hospital with the diagnosis of acute PE between May 2012 and June 2013 was retrospectively reviewed. 93 patients who were in sinus rhythm and whose data were suitable for $\mathrm{QT}$ interval and $\mathrm{P}$ wave analyses were included to the study. Analyses of corrected QT interval dispersion (QTCd) and P wave dispersion $(\mathrm{Pd})$ were performed for each patients.

RESULTS: Among the study population, 12 patients (13\%) died and 81 patients (87\%) lived after the diagnosis of PE. PD values of deaths were significantly higher than those who survived $(59.2 \pm 21.2 \mathrm{msec}$ versus $44.8 \pm 13.5 \mathrm{msec}$ respectively, $\mathrm{p}=0.04)$. Moreover, QTcd values of deaths were also significantly higher than the survivors (105.5 msec (99-119) versus $80 \mathrm{msec}(74-88)$ respectively, $\mathrm{p}<0.001$ ). The sensitivity of $\mathrm{Pd}>64.5 \mathrm{msec}$ for prediction of early mortality was found to be $58.3 \%$ with a specificity of $97.5 \%(p=0.017)$ where the sensitivity of Qtcd $>97$ msec for prediction of early mortality was found to be $83.3 \%$ with a specificity of $82.7 \%(p<0.001)$.

CONCLUSION: Both electrocardiography parameters Pd and QTCd may be used as a good and useful markers. We found that, in comparison to Pd, QTcd is superior to detect those who were under potential high risk and who need more aggressive treatment in the course of acute PE.

KEYWORDS: Early death, P wave dispersion, predictor, pulmonary embolism, QT interval dispersion
Özet

AMAÇ: Akut pulmoner emboli varlığında P dalgası ve QT dispersiyonlarının erken ölüm ile ilişkisini sorgulamak ve birbiriyle kıyaslamak istedik.

GEREÇ VE YÖNTEMLER: Mayıs 2012 ve Haziran 2013 tarihleri arasındaki 124 hastanın arşiv verileri retrospektif olarak analiz edildi. Bunların içinden sinüs ritminde olan ve verileri QT ve P dalga analizlerine uygun olanlar çalışmaya dahil edildi. Her bir hasta için düzeltilmiş QT intervali ve $\mathrm{P}$ dalga dispersiyon analizleri yapıldı.

BULGULAR: Çalışma grubundaki 12 hasta (\%13) ölürken 81 hasta (\%87) akut pulmoner emboli tanısı sonrası yaşadı. Ölülerin $\mathrm{P}$ dalga dispersiyonu değerleri yaşayanlardan anlamlı olarak daha yüksek saptandı (sırası ile 59.2 $\pm 21.2 \mathrm{msn}$ 'e kıyasla $44.8 \pm 13.5 \mathrm{msn}, \mathrm{p}=0.04$ ). Ayrıca, ölülerin düzeltilmiş QT dsipersiyonu değerleri de yaşayanlardan anlamlı olarak daha yüksek saptandı (sırasıyla 105.5 $\mathrm{msn}(99-119)$ ve $80 \mathrm{msn}$ (74-88), $\mathrm{p}<0.001)$. $P$ dalga dispersiyonunun $>64.5 \mathrm{msn}$ için erken ölümü öngörme sensitivitesi $\% 58,3$, spesifitesi $\% 97,5$ ( $p=0.017$ ) olarak bulunurken, düzeltilmiş QT dispersiyonunun $>97$ msn için erken ölümü öngörme sensitivitesi $\% 83,3$, spesifitesi $\% 82,7$ olarak bulundu $(\mathrm{p}<0.001)$.

SONUÇ: Her iki elektrokardiyografi parametresi $P$ dalga dispersiyonu ve QT dispersiyonu iyi ve yararlı markerlar olarak görünmektedir. Bu çalışmada, akut pulmoner emboli seyrinde daha yüksek riskli hastaları ve daha yoğun medikal tedaviye ihtiyacı olanları saptamada, düzeltilmiş QT dispersiyonunun $\mathrm{P}$ dalga dispersiyonuna kıyasla daha değerli olduğunu gösterdik.

ANAHTAR KELIMELER: Erken olum, P dalga dispersiyonu, prediktör, pulmoner emboli, QT dispersiyonu

\section{Introduction}

Acute pulmonary embolism (PE) remains associated with high morbidity and mortality rates despite advanced therapeutic options. This may partly take root from the deficiency of initial prognostic assessment of patients. Both European and American guidelines suggests more aggressive treatment, i.e. administration of thrombolytic agents, for those who are under high risk of early mortality (1). Thus, determination of the risk class is mandatory. Despite effortful work-up and significant progress on the prognosis of patients with pulmonary embolism, there is still a need of novel clinical markers for the prediction of high risk patients. 
Electrocardiography (ECG) is a simple and noninvasive test for the diagnosis of diseases or situations that involve the heart. In the course of pulmonary embolism, acute haemodynamical disturbances of the pulmonary vascular bed and their effects on both right ventricle and atrium may be reflected by the surface ECG.

Surface ECG with its shining parameters like QT and P wave dispersions has been shown to provide valuable information in variety of diseases. QT dispersion is the difference in re-polarization duration among electrocardiographic leads. It provides information about the heterogeneity of recovery time of the myocardium. Studies have shown that the prolongation of heart rate-corrected QT interval (QTc) and QTcd is persion (QTcd) are associated with poor outcome in a variety of diseases (2-5). Recently Ermiş et al. showed that QTcd was positively associated with risk status of pulmonary embolism (6).

QT dispersion is the difference in re-polarization duration among electrocardiographic leads. It provides information about the heterogeneity of recovery time of the myocardium. Studies have shown that the prolongation of heart rate-corrected QT interval (QTC) and QTc dispersion (QTcd) are associated with poor outcome in a variety of diseases (2-5).

\section{Materials and Methods}

\section{Patients}

This study was conducted in Adnan Menderes University Faculty of Medicine in Aydın, Turkey. The archive data of 124 patients who had been hospitalized in Faculty Hospital with the diagnosis of pulmonary embolism (whom had final diagnosis after the exact demonstration of thrombus in pulmonary arteries via computed tomography) between May 2012 and June 2013 was retrospectively reviewed. Ninety three patients who were in sinus rhythm and whose data were suitable for QT and P wave analyses were included to the study.

Patients' ages, co-morbidities, symptoms, hemodynamic conditions, all cause mortality rates during hospitalization, total hospitalization times, radiographic test results and laboratory findings were recorded and ECG's that had been obtained during the admission were evaluated. Patients with atrial fibrillation during admission or excessive noises in ECG were excluded from the study. The study protocol was approved by the Ethic Committee of University of Adnan Menderes and all procedures followed were in accordance with the ethical standards of the responsible committee on human experimentation (institutional and national) and with the Helsinki Declaration of 1975, as revised in 2008.

\section{Diagnosis of pulmonary embolism}

The diagnosis of pulmonary embolism (PE) is made by spiral computerized tomography (CT) pulmonary angiography with the direct visualization of an intraluminal filling defect in the course of acute symptoms and signs suggesting pulmonary embolism.

\section{Analyses of ECG, QTd and Pdmeasurements}

For the analyses, We used standard 12 lead ECG traces obtained on the initial admission of patients. The records were taken in supine posture at $25 \mathrm{~mm} / \mathrm{second}$ paper speed at $10 \mathrm{~mm} / \mathrm{mV}$ amplitude. The measurements were performed manually with the help of magnifying glass by an experienced two cardiologists who were blinded to the clinical data of the patients. Three consecutive beats were used for the analyses where at least 10 leads were analyzable in ECGs.
The QT intervals were measured from the onset of the QRS to the end of the T-wave, defined as the return to T-P isoelectric baseline. Only monophasic well-defined T-waves were accepted for measurement. When U-waves were present, the QT interval was measured to the nadir of the curve between the $T$ and the $U$ waves. The QTd was defined as the difference between the maximum and minimum QT values. Bazett's formula (QTc $=\mathrm{QT} / \sqrt{ } \mathrm{RR})$ was used for the QTc and QTcd analyses (12).

P-wave duration was measured from the point of junction between isoelectric line and the beginning of $P$ wave deflection, to the point of junction between the end of $\mathrm{P}$ - wave deflection and isoelectric line. $\mathrm{Pd}$ is defined as the difference between the maximum (Pmax) and the minimum P-wave (Pmin) durations occurring in any of the 12 leads.

To estimate intra-observer and inter-observer variability, randomized 33 ECG's were re-analyzed and measurements were repeated by two cardiologists. For determining the intra-observer variability, 33 ECG tracings were evaluated by the same investigator on two different occasions. To assess the inter-observer variation, all ECG tracings were analyzed by a second independent investigator who was blind to the results obtained by the first one.

\section{Statistical analysis}

To determine the normality of numeric variables we used Kolmogorov-Smirnov test. We used independent sample test to compare the two groups by means of the numeric variables that were normally distributed. We presented descriptive statistics as mean \pm standard deviation. We used Mann-Whitney $U$ test to compare the two groups by means of numeric variables that were not normally distributed and presented descriptive statistics as median (25-75 percentiles). To analyze the categorical data, a chi-square test was used and descriptive statistics are presented as frequency (\%). The Spearman's rho correlation analysis was used to determine the reliability and reproducibility of electrocardiographic parameters by evaluating their inter-observer and intra-observer variability. Receiver Operating Characteristic (ROC) curve was used to determine the cut-off point of Qtcd and Pd. The p values below 0.05 were considered statistically significant.

\section{Results}

Reproducibility of the determination of QTCd and Pd dispersions were high in both intra-observer and inter-observer comparisons. To estimate intra-observer and inter-observer variability, randomized 33 ECG's were re-analyzed and measurements were repeated by both cardiologists. Intra-observer variability for QTcd ( $r=0.976$, $\mathrm{p}<0.001)$ and $\mathrm{Pd}(\mathrm{r}=0.988, \mathrm{p}<0.001)$ were non significant. Inter-observer variability between two cardiologists for the estimation of QTcd $(r=0.982, p<0.001)$ and $\mathrm{Pd}(r=0.994, p<0.001)$ were also non significant.

Among the study population, 12 patients (13\%) died and 81 patients (87\%) lived after the diagnosis of acute PE. P wave dispersion values of deaths were significantly higher than those who survived (59.2 \pm 21.2 msec versus $44.8 \pm 13.5 \mathrm{msec}$ respectively, $\mathrm{p}=0.040)$. Moreover, QTcd values of deaths were also significantly higher than the survivors (105.5 msec (99-119) versus $80 \mathrm{msec}$ (74-88) respectively, $(p<0.001)$. 
Baseline characteristics of the study population was shown in the Table 1. Among the study population mean age was $62 \pm 16.6$ year. The frequency of female in the population was $44 \%(n=41)$, where $56 \%$ were male $(n=52)$. Frequency of hypertension was $49.5 \%(n=46)$, diabetes mellitus was $31 \%(n=29)$, chronic obstructive pulmonary disease (COPD) was $32 \%(n=30)$, deep venous thrombosis was $18 \%$ $(n=17)$ and history of malignancy was $22.5 \%(n=21)$ in the study group. The $49.5 \%(n=46)$ of the population were smokers. Mean hemoglobin $(\mathrm{Hb})$ of the population was $10.5 \pm 1.7 \mathrm{~g} / \mathrm{dL}$, troponin I was 0 $\mathrm{mg} / \mathrm{dL}$ (0-0.5), D-dimer was $3200 \mu \mathrm{g} / \mathrm{dL}$ (1700-5300). Mean QTcd was $87 \pm 21.4 \mathrm{msec}$ and $\mathrm{Pd}$ was $46.6 \pm 15.3 \mathrm{msec}$. In the study, longest $\mathrm{p}$ wave duration was found to be $97.5 \pm 16.1 \mathrm{msec}$ and shortest $p$ wave duration was $51 \pm 14 \mathrm{msec}$. $24 \%(n=12)$ of the patients were hemodynamically unstable and to the $8.6 \%(n=8)$ of total group had taken thrombolytic therapy. There wasn st any major bleeding and minor bleeding occurred in $6.5 \%(n=6)$ of the patients. Total hospitalization time was $7.3 \pm 7$ days and hospitalization to death time was $5.5 \pm 4.5$ days (Table 1).

Comparison of baseline characteristics of the deaths and survivors in the course of acute PE was shown in Table 2. There was not any significant difference between the survivors and deaths by means

Table 1. Baseline characteristics of the study population.

\begin{tabular}{|c|c|}
\hline Variables & Descriptive Statistics \\
\hline Age(years) & $62 \pm 16.6$ \\
\hline \multicolumn{2}{|l|}{ Sex } \\
\hline Female & $41(44 \%)$ \\
\hline Male & $52(56 \%)$ \\
\hline Diabetes mellitus & $29(31 \%)$ \\
\hline Hypertension & $46(49.5 \%)$ \\
\hline Chronic obstructive pulmonary disease & $30(32 \%)$ \\
\hline Deep venous thrombosis & $17(18 \%)$ \\
\hline History of malignancy & $21(22.5 \%)$ \\
\hline Presence of hemodynamic Instability & $22(24 \%)$ \\
\hline Total hospitalization time days & $7.3 \pm 7$ \\
\hline Hospitalization to death time days & $5.5 \pm 4.5$ \\
\hline Death & $12(13 \%)$ \\
\hline Smoking & $46(49.5 \%)$ \\
\hline Thrombolytic therapy administered & $8(8.6 \%)$ \\
\hline Minor bleeding & $6(6.5 \%)$ \\
\hline Major bleeding & $0(0 \%)$ \\
\hline Troponin I(mg/dl) & $0(0-1.2)$ \\
\hline D-dimer( $\mu \mathrm{g} / \mathrm{dL})$ & $3200(1700-5300)$ \\
\hline Hemoglobin (g/dL) & $11.7 \pm 1.9$ \\
\hline QT dispersion(msec) & $87 \pm 21.4$ \\
\hline P wave dispersion(msec) & $46.6 \pm 15.3$ \\
\hline Longest $\mathrm{P}$ wave duration(msec) & $97.5 \pm 16.1$ \\
\hline Shortest $\mathrm{P}$ wave duration(msec) & $51 \pm 14$ \\
\hline
\end{tabular}

of age, smoking habit, and accompanying diseases like diabetes, hypertension, chronic obstructive pulmonary disease (COPD) and deep venous thrombosis ( $p>0.05$ ) (Table 2). However there is a significant difference by means of gender, favoring males for death $(75 \%$ versus, $25 \%, p=0.046)$. $D$-dimer levels were significantly higher in deaths (4750 $\mu \mathrm{g} / \mathrm{dL}$ (3200-6100) versus 2800 $\mu \mathrm{g} / \mathrm{dL}$ (1500-5200), $\mathrm{p}=0.023)$. In

Table 2. Comparison of baseline characteristics of the deaths and survivors in the course of acute pulmonary embolism.

\begin{tabular}{lccc}
\hline & $\begin{array}{c}\text { Deaths } \\
(n=12)\end{array}$ & $\begin{array}{c}\text { Survivors } \\
(n=81)\end{array}$ & $\mathbf{p}$ \\
\hline Age(year) & $69.5(65-76)$ & $67(49-75)$ & 0.268
\end{tabular}

Sex

Female

$3(25 \%) \quad 49(60.5 \%)$

Male

$9(75 \%)$

$32(39.5 \%)$

0.046

Deep venous thrombosis

(+)

$2(16.7 \%) \quad 15(18.5 \%)$

$(-)$

$10(83.3 \%) \quad 66(81.5 \%)$

1.000

Diabetes mellitus

$(+)$

$(-)$

$4(33 \%) \quad 25(31 \%)$

$8(67 \%) \quad 56(69 \%)$

1.000

Hypertension

(+)

$6(50 \%) \quad 40(49.4 \%)$

$(-)$

$6(50 \%)$

$41(50.6 \%)$

1.000

Chronic obstructive pulmonary disease

(+)

$3(25 \%) \quad 27(33 \%)$

$(-)$

$9(75 \%) \quad 54(67 \%)$

0.745

Malignancy

(+)

$(-)$

$7(58 \%) \quad 14(17 \%)$

$5(42 \%)$

$67(83 \%)$

0.004

Smoking

(+)

$9(75 \%) \quad 37(46 \%)$

$(-)$

$3(25 \%) \quad 44(54 \%)$

0.113

Hemodynamic Instability

(+)

$(-)$

$8(67 \%) \quad 14(17 \%)$

$4(33 \%) \quad 67(83 \%)$

0.001

Corrected QT interval dispersionmsec

$105.5(99-119)$

$80(74-88)$

$<0.001$

P wave dispersion $(\mathrm{msec})$

$59.2 \pm 21.2$

$44.8 \pm 13.5$

0.040

Hemoglobin(g/dL)

$10.5 \pm 1.7$

$12 \pm 1.8$

0.014

Troponin I(mg/dL)

$5.3(1.7-23)$

$0(0.0-0.5)$

$<0.001$

D-dimer( $\mu \mathrm{g} / \mathrm{dL})$

4750

2800

$\begin{array}{lll}(3200-6100) & (1500-5200) & 0.023\end{array}$

Thrombolytic therapy

(+)

$3(25 \%) \quad 5(6.2 \%)$

$(-)$

$9(75 \%) \quad 76(93.8 \%)$

0.064 
addition, troponin I serum levels were significantly higher in deaths $(5.3 \mathrm{mg} / \mathrm{dL}(1.7-23)$ versus $0 \mathrm{mg} / \mathrm{dL}(0-0.55), \mathrm{p}<0.001)$ and hemoglobin levels were significantly lower $(10.5 \mathrm{~g} / \mathrm{dL} \pm 1.7)$ versus $(12 \mathrm{~g} /$ $\mathrm{dL} \pm 1.9, \mathrm{p}=0.014$ ) (Table 2 ). As compared by means of hemodynamic instability, the difference between the deaths and survivors was significant $(67 \%(n=8)$ versus $17 \%(n=14)$ respectively, $p=0.001)$. Mali gnancy was significantly frequent in deaths $(58.3 \%$ versus $17.3 \%$, $\mathrm{p}=0.004)$.

According to ROC curve, we found that the for prediction of early mortality, the cut point, area under the curve (AUC), sensitivity and specificity were $\mathrm{Pd}>64.5 \mathrm{msec}, 0.710,58.3 \%$ and $97.5 \%$ respectively $(p=0.017)$ (Figure 1). In addition, according to ROC curve, we found that the cut point, area under the curve (AUC), sensitivity and specificity were QTcd> $97 \mathrm{msec}, 0.836,83.3 \%$ and $82.7 \%$ respectively $(p<0.001)$ for the prediction of early mortality in patients with acute PE (Figure 1).

\section{Discussion}

To the best of our knowledge the present study is the first to demonstrate the effectiveness of P-wave dispersion for predicting the early death in patients with pulmonary embolism. Moreover, we showed that QT dispersion also constitutes an independent factor for predicting early mortality in this group of patients. As compared to each other QTcd seems to be superior to Pd.

Acute PE may present with liJttle pulmonary embolus that does not cause any symptoms or with huge embolus that causes increased rates of right ventricular (RV) heart failure, shock and mortality. Previous studies demonstrated that age, compromised haemodynamic status, plasma levels of creatinine, NT- pro brain natriuretic peptide (BNP) and troponin I levels could be accepted as prognostic markers in patients with acute PE. Especially, the detection of the severity of RV failure has strategic importance as it has great predictive value for the mortality (13). The most useful method for the evaluation

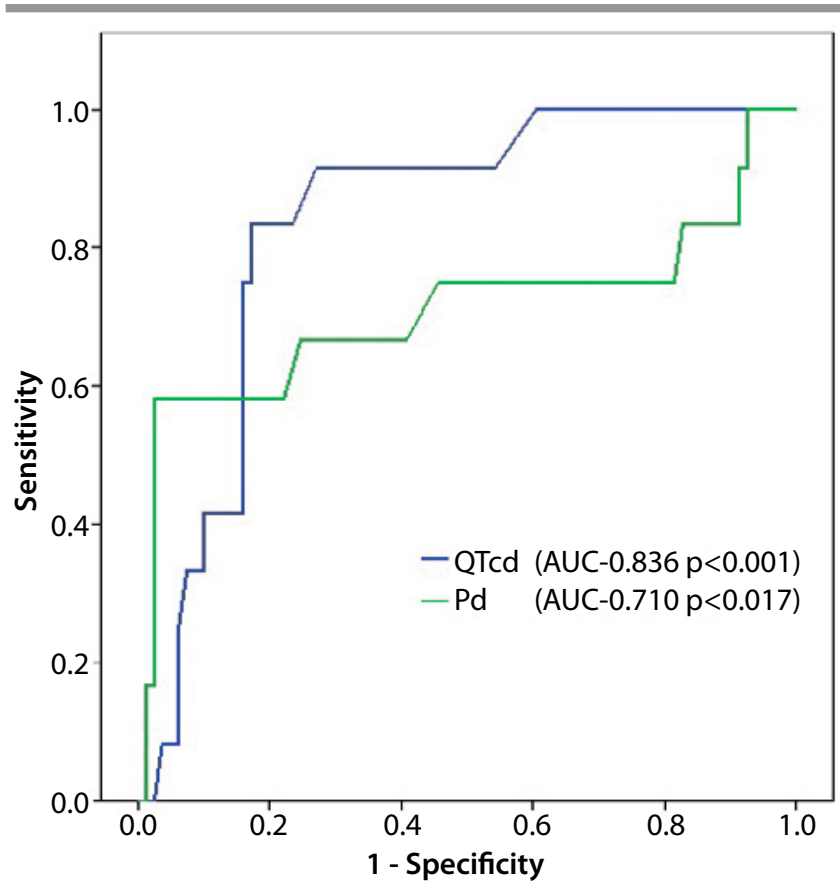

Figure 1. ROC curves of QTcd and Pd to predict early mortality of right ventricle is echocardiography but it needs experience. The prediction of the severity of pulmonary embolism and patients who hashigh risk of mortality require some novel practical tactics other than echocardiographic examination.

There are several familiar ECG abnormalities associated with acute $P E$, but none are highly specific or sensitive. In patients with RV failure, the ECG may show sinus tachycardia, signs of RV strain, repolarization abnormalities, or ischemia including a complete or incomplete right bundle branch block, a right ward axis (>90 degrees), an S1Q3T3 pattern, a Qr in lead V1, ST elevation in V1, or precordial Twave inversions. However, approximately two-thirds of patients with massive or submassive PEs exhibit no such classical changes on ECG. Recently a novel parameter of surface ECG, QT dispersion was shown to have an important role in the prediction of mortality in acute PE (6). The rationale of this close relation of QTd and the prognosis of PE maybe partly explained by acute repolarization changes of the overloaded RV. QTdis suggested to be a good marker for the detection of inhomogeneity of ventricular recovery times and advanced heterogeneity of repolarization leading to increased QTd may be expected especially in the setting of acute RV failure (14). Of interest, Ermiş et al. suggested that the sensitivity of QTcd $>71.5 \mathrm{~ms}$ for prediction of mortality was $71 \%$ with a specificity of $73 \%$ in patients with acute pulmonary embolus (6). Moreover, QTcd was also shown to be related to pulmonary hypertension which is alsoa common finding of pulmonary embolism $(15,16)$. The findings of our study was compatible with the literature. We found that the sensitivity of Qtcd $>97 \mathrm{msec}$ for prediction of early mortality was $83.3 \%$ with a specificity of $82.7 \%$ $(p<0.001)$ (Figure 1). Previously it was suggested that the QTd may be affected by the number of measurable leads (17). In the current study, we showed importance on this subject and we eliminated the ECG's that did not have at least 10 leads for effective analysis.

Pd is another novel parameter of ECG and regarded as a marker of a trial depolarization heterogeneity (18). It is also suggested to reflect abnormalities of atrial size and structure (19). In the setting of acute RV failure, when RV end-diastolic volumes and pressures increase, increased RV wall stress leads to reduced RV stroke volume. Elevated RV end-diastolic volumes also cause tricuspid annular dilatation, which worsens tricuspid valve insufficiency and increases right atrial pressure and atrial wall tension. Previously Barra et al. demonstrated that in the course of acute $\mathrm{PE}$, atrial fibrillation is a predictor of bad prognosis (20). Moreover, recently it is was shown that Pd was a predictor of atrial fibrillation (21). In the light of cumulative data, we made the hypothesis that Pd maybe associated with the prognosis of acute PE and we demonstrated the close relation of high Pd levels with early death. We found that the sensitivity of Pd>64.5 msec for prediction of early mortality was $58.3 \%$ with a specificity of $97.5 \%$ $(p=0.017)$ (Figure 1).

\section{Conclusion}

Despite adequate treatment there is still possibility of high mortality and further need for thrombolysis in some group of patients who were initially regarded to be in the intermediate risk group. To detect those who were under potential high risk and who need more aggressive treatment, ECG parameters like Pd and QTcd constitute good and very useful predictive markers. However as compared to each other QTcd seems to be superior to Pd for detecting high risk patients. 
Ethics Committee Approval: Ethics committee approval was received for this study from the ethics committee of University of Adnan Menderes.

Peer-review: Externally peer-reviewed.

Author contributions: Concept - Ç.A., U.E.; Design - Ç.A., U.E., I.K.Ö.; Supervision - Ç.A., H.G., C.Z.; Resource - E.D., M.A.; Analysis\&/or Interpretation - Ç.A., I.K.Ö.; Literature Search - H.G., C.Z.; Writing - Ç.A., U.E., I.K.Ö.; Critical Reviews - Ç.A., I.K.Ö., U.E.

Conflict of Interest: No conflict of interest was declared by the authors.

Financial Disclosure: The authors declared that this study has received no financial support.

Etik Komite Onayı: Bu çalışma için etik komite onayı Adnan Menderes Üniversitesi'nden alınmıştır.

Hakem değerlendirmesi: Dış bağımsız.

Yazar Katkıları: Fikir - Ç.A., U.E.; Tasarım - Ç.A., U.E., I.K.Ö.; Denetleme - Ç.A., H.G., C.Z.; Veri toplanması ve/veya işlemesi - E.D., M.A.; Analiz ve/veya yorum Ç.A., İ.K.Ö.; Literatür taraması - H.G., C.Z.; Yazıyı yazan - Ç.A., U.E., İ.K.Ö.; Eleştirel Inceleme - Ç.A., I.K.Ö., U.E.

Çıkar Çatışması: Yazarlar çıkar çatışması bildirmemişlerdir.

Finansal Destek: Yazarlar bu çalışma için finansal destek almadıklarını beyan etmişlerdir.

\section{References}

1. Torbicki A, Perrier A, Konstantinides S, et al. Guidelines on the diagnosis and management of acute pulmonary embolism: The Task Force for the Diagnosis and Management of Acute Pulmonary Embolism of the European Society of Cardiology (ESC). Eur Heart J 2008; 29: 2276-315. [CrossRef]

2. Perkiömäki JS, Koistinen MJ, Yli-Mäyry S, Huikuri HV. Dispersion of the QT interval in patients with and without susceptibility to ventricular tachyarrhythmias after previous myocardial infarction. J Am Coll Cardiol 1995; 26: 174-9. [CrossRef]

3. Barr CS, Naas A, Freeman M, Lang CC, Struthers AD. QT dispersion and sudden unexpected death in chronic heart failure. Lancet 1994; 343: 327-9. [CrossRef]

4. Ichkhan K, Molnar J, Somberg J. Relation of left ventricular mass and QT dispersion in patients with systematic hypertension. Am J Cardiol 1997; 79: 508-11. [CrossRef]

5. Hong-liang Z, Qin L, Zhi-hong L, et al. Heart rate-corrected QT interval and QT dis-persion in patties with pulmonary hypertension. Wien KlinWochenschr 2009; 121: 330-3. [CrossRef]

6. Ermıs N, Ermıs H, Sen N, Kepez A, Cuglan B. QT dispersion in patients with pulmonary embolism. Wien KlinWochenschr 2010; 122: 691-7. [CrossRef]
7. Nussinovitch N, Livneh A, Katz K, et al. P wave dis-persion in familial Mediterranean fever. Rheumatol Int 2011; 31: 1591-4. [CrossRef]

8. Michelucci A, Bagliani G, Colella A, et al. P wave assessment: State of the art update. Card Electrophysiol Rev 2002; 6: 215-20. [CrossRef]

9. Kurt M, Tanboğa IH, Karakaş MF, et al. The relationship between atrial electromechanical delay and $\mathrm{P}$-wavedispersion with the presence and severity of metabolic syndrome. Turk Kardiyol Dern Ars 2012; 40: 663-70. [CrossRef]

10. Medford AR. Arrhythmias in COPD: consider P-wavedispersion and pulmonary hypertension, too. Chest 2013; 143: 579. [CrossRef]

11. Sap F, Karataş Z, Altin H, et al. Dispersion durations of P-wave and QT interval in children with congenital heart disease and pulmonary arterial hypertension. Pediatr Cardiol 2013; 34: 591-6. [CrossRef]

12. Bazett $\mathrm{HC}$. An analysis of the time-relations of electrocardiograms. Heart 1920; 7: 353-70

13. ten Wolde $M$, Söhne M, Quak E, Mac Gillavry M, Büller HR. Prognostic value of echocardiographically assessed right ventricular dysfunction in patients with pulmonary embolism. Arch Intern Med 2004; 164: 1685-9. [CrossRef]

14. Zabel M, Portnoy S, Franz MR. Electrocardiographic indexes of dispersion of ventricular repolarization: an isolated heart validation study. J Am Coll Cardiol 1995; 25: 746-52. [CrossRef]

15. Hong-liang Z, Qin L, Zhi-hong L, et al. Heart rate-corrected QT interval and QT dispersion in patients with pulmonary hypertension. Wien Klin Wochenschr 2009; 121: 330-3. [CrossRef]

16. Sap F, Karataş Z, Altin H, et al. Dispersion durations of P-wave and QT interval in children with congenital heart disease and pulmonary arterial hypertension. Pediatr Cardiol 2013; 34: 591-6. [CrossRef]

17. Day CP, McComb M, Matthews J, Campbell RW. Reduction in QT dispersion by sotalol following myocar-dial infarction. Eur Heart J 1991; 12 423-7.

18. Dogan U, Dogan EA, Tekinalp M, et al. P-wave dispersion for predicting paroxysmal atrial fibrillation in acute ischemic stroke. Int J Med Sci 2012; 9: 108-14. [CrossRef]

19. HashemiJazi M, Amirpour A, Zavvar R, Behjati M, Gharipour M. Predictive value of $\mathrm{P}$-wave duration and dispersion in post coronary artery bypass surgery atrial fibrillation. ARYA Atheroscler 2012; 8: 59-62.

20. Barra SN, Paiva LV, Providência R, Fernandes A, Leitão Marques A. Atrial fibrillation in acute pulmonary embolism: prognostic considerations. Emerg Med J 2014; 31: 308-12. [CrossRef]

21. Elmoniem AA, El-Hefny N, Wadi W. P Wave Dispersion (PWD) as a predictor of Atrial Fibrillation (AF). Int J Health Sci (Qassim) 2011; 5(2 Suppl 1): 25-6. 